\title{
Soil carbon, after 3 years, under short-rotation woody crops grown under varying nutrient and water availability
}

\author{
Felipe G. Sanchez ${ }^{\mathrm{a}, *}$, Mark Coleman ${ }^{\mathrm{b}}$, Charles T. Garten Jr. ${ }^{\mathrm{c}}$, Robert J. Luxmoore ${ }^{\mathrm{c}}$, \\ John A. Stanturf ${ }^{\mathrm{d}}$, Carl Trettin ${ }^{\mathrm{e}}$, Stan D. Wullschleger ${ }^{\mathrm{c}}$ \\ ${ }^{a}$ USDA Forest Service, Southern Research Station, Forestry Sciences Laboratory, 3041 Cornwallis Road, Research Triangle Park, NC 27709, USA \\ ${ }^{\mathrm{b}}$ USDA Forest Service, Southern Research Station, Savannah River Institute, P.O. Box 700, New Ellenton, SC 29809, USA \\ ${ }^{\mathrm{c}}$ Environmenal Sciences Division, Oak Ridge National Laboratory, Oak Ridge, TN 38731, USA \\ ${ }^{\mathrm{d}}$ USDA Forest Service, Southern Research Station, Forestry Sciences Laboratory, 320 Green Street, Athens, GA 30602, USA \\ ${ }^{\mathrm{e}}$ USDA Forest Service, Southern Research Station, Center for Forested Wetlands Research, 2730 Savannah Highway, Charleston, SC 29414, USA
}

Received 14 December 2006; received in revised form 20 April 2007; accepted 1 June 2007

Available online 12 July 2007

\begin{abstract}
Soil carbon contents were measured on a short-rotation woody crop study located on the US Department of Energy's Savannah River Site outside Aiken, SC. This study included fertilization and irrigation treatments on five tree genotypes (sweetgum, loblolly pine, sycamore and two eastern cottonwood clones). Prior to study installation, the previous pine stand was harvested and the remaining slash and stumps were pulverized and incorporated $30 \mathrm{~cm}$ into the soil. One year after harvest soil carbon levels were consistent with preharvest levels but dropped in the third year below pre-harvest levels. Tillage increased soil carbon contents, after three years, as compared with adjacent plots that were not part of the study but where harvested, but not tilled, at the same time. When the soil response to the individual treatments for each genotype was examined, one cottonwood clone (ST66), when irrigated and fertilized, had higher total soil carbon and mineral associated carbon in the upper $30 \mathrm{~cm}$ compared with the other tree genotypes. This suggests that root development in ST66 may have been stimulated by the irrigation plus fertilization treatment.
\end{abstract}

Published by Elsevier Ltd.

Keywords: Short-rotation woody crops; Soil carbon; Stabilized carbon; Irrigation; Fertilization

\section{Introduction}

Plantation forest managers are under pressure to manage their forests to rapidly produce biomass to meet the growing global demands for fiber and wood products. Strategies employed by land managers include using improved genetic material, intensive site preparation, competition control, pest control and site resource management [1-5]. These strategies have been successful in increasing biomass production over a relatively short period of time in plantation forests [6-9]. An additional

\footnotetext{
*Corresponding author. Tel.: + 1919549 4043; fax: + 19195494047.

E-mail addresses: fsanchez@fs.fed.us (F.G. Sanchez), mcoleman01@fs.fed.us (M. Coleman),gartenctjr@ornl.gov (C.T. Garten Jr.), luxmoorerj@ornl.gov (R.J. Luxmoore), jstanturf@fs.fed.us (J.A. Stanturf), ctrettin@,fs.fed.us (C. Trettin), wullschlegsd@ornl.gov (S.D. Wullschleger).
}

benefit of these rapidly growing woody crops is the potential to increase the carbon $(\mathrm{C})$ storage belowground. Johnson [10] identified the need to determine management effects on soil properties and soil $\mathrm{C}$ sequestration in intensively managed systems. Concurrent with the increase in aboveground biomass of intensively managed shortrotation woody crops is the increase in belowground biomass. The benefits of greater belowground biomass production may have positive benefits to soil $\mathrm{C}$ storage [11-13]. During stand development, root production could increase soil C stocks substantially [14-18]. For example, Devine et al. [19] attributed soil C gains in a soybeansycamore (Platanus occidentalis) - no-till corn rotation on an agricultural silt-loam soil to the contribution of 4-5-year-old sycamore plantations within the rotation. Rates of soil $\mathrm{C}$ accrual under six tree plantations during the first decade following establishment in Tennessee and 
South Carolina ranged from 40 to $170 \mathrm{~g} \mathrm{C} \mathrm{m}^{-2}$ year ${ }^{-1}$, and most soil $\mathrm{C}$ at each site was associated with the silt-clay soil fraction [20]. Additionally, at the end of a rotation the roots left after harvest can also have a strong impact on soil C contents [21-23].

Prior to planting, intensive site preparation practices that include the incorporation of organic matter to the soil have shown promise in increasing soil C stocks [24]. Utilizing the CO2FIX model to estimate the amount of C sequestered in a hypothetical hybrid poplar stand grown in the southern United States, Buford and Stokes [25] predicted that soil $\mathrm{C}$ contents would increase by approximately $100 \mathrm{Mg} \mathrm{ha}^{-1}$, over five rotations, when the previous stand's forest slash was incorporated into the soil after each rotation. In separate studies where forest slash was incorporated into soils with different initial soil $\mathrm{C}$ contents and hydrology [26] and different textures and amounts of material incorporated [27], early $(<5$ years $)$ results provided support for the idea that $\mathrm{C}$ could be sequestered in the soil through the incorporation of forest slash.

An intensively managed study was installed in 2000 to examine the effects of resource (i.e., water and nutrients) availability on $\mathrm{C}$ and nutrient balance and to define the processes controlling tree growth response to resource availability for five tree genotypes [28]. As a component of that larger study, this manuscript tests the hypothesis that increasing resource (i.e., water and nutrients) availability will increase soil $\mathrm{C}$ contents across all genotypes and for each genotype individually. Another hypothesis tested is that site preparation will increase both total soil $\mathrm{C}$ and stabilized soil $\mathrm{C}$ contents.

\section{Materials and methods}

\subsection{Site description}

The study site is located on the US Department of Energy's Savannah River Site (DOE-SRS), a National Environmental Research Park ( $\left.33^{\circ} 23^{\prime} \mathrm{N} ; 81^{\circ} 40^{\prime} \mathrm{E}\right)$. Details are provided in Coleman et al. [28], a brief description follows. The mild climate has $17.9^{\circ} \mathrm{C}$ mean annual temperatures and $1214 \mathrm{~mm}$ mean annual precipitation. The soils are primarily in the Blanton series (loamy, siliceous, semiactive, thermic Grossarenic Paleudults) [29]. The previous vegetation on the site was either 11-year-old loblolly pine (Pinus taeda L.) or 35-year-old longleaf pine (Pinus palustris Mill.) stand, which were harvested in April-May of 1999.

After harvesting, slash ( $>15 \mathrm{~cm}$ diameter) were removed off the plots. The residual debris and stumps were then homogenized and tilled $30 \mathrm{~cm}$ into the soil with an RS-500 Reclaimer/Stabilizer (CMI Corporation, Oklahoma City). After tillage, dolomite lime was applied at a rate of 3.4 $\mathrm{Mg} \mathrm{ha}^{-1}$ and disked into the soil to achieve a target soil $\mathrm{pH}$ of 6.5 .

\subsection{Plant material}

In this experiment, five genotypes were examined: two eastern cottonwood clones (Populus deltoides), sycamore (Platanus occidentalis L.), sweetgum (Liquidambar styraciflua L.) and loblolly pine. Two eastern cottonwood clones (ST66 and S7C15) were selected to give a greater genetic representation than would be possible with one clone. The other genotypes were single half-sibling families and had more genetic diversity than cottonwood. Planting of loblolly pine, sycamore and sweetgum bare-root seedlings occurred in February 2000, while cottonwood cuttings (1-2 cm diameter) were planted in April 2000.

\subsection{Experimental design}

The trees were planted $(2.5 \mathrm{~m} \times 3 \mathrm{~m}$ spacing $)$ with 294 trees within each treatment plot. Within each treatment plot, there was a measurement plot containing 54 trees. This resulted in a border more than $12 \mathrm{~m}$ wide. The core study was set up in a three way, complete factorial, split plot design including fertilization, irrigation and five tree species. The treatments examined in this study included (1) control (CON) (neither irrigation nor fertilization), (2) irrigated (I), (3) fertilized (F) and (4) a combination of irrigation and fertilization (IF). Tree genotypes were randomly assigned to whole plots, which were then split into four subplots. The irrigation and fertilization treatments were then randomly assigned to the subplots. Irrigation was done by drip irrigation at a rate of $5 \mathrm{~mm}$ of water day ${ }^{-1}$ to meet evaporative demand [28]. A complete, balanced fertilizer (7-7-7) was applied weekly as liquid injected into irrigation lines. The sum of weekly applications equaled the target annual rate. Annual nitrogen $(\mathrm{N})$ rates were ramped up to meet increasing demand based on growth rates. For cottonwood and sycamore 40,80 and $120 \mathrm{~kg} \mathrm{~N}^{-1}$ year $^{-1}$ was applied in years 1, 2 and 3, respectively. For sweetgum and pine the $40 \mathrm{~kg} \mathrm{Nha}^{-1}$ year $^{-1}$ rate applied in years 1 and 2 was increased to 80 in year 3 . The fertilizer was applied through a drip irrigation system on both the irrigated and nonirrigated plots. On the non-irrigated plots, only enough water to apply the fertilizer and clear out the lines was used $\left(0.7 \mathrm{~mm}\right.$ of water day $\left.{ }^{-1}\right)$.

In addition to the plots in the core design, five plots were harvested but never tilled nor planted. Native vegetation, primarily an upland oak pine mix, was allowed to reestablish on these plots. Although not part of the core study, and not included in the treatment and genotype analyses, these plots were sampled to examine for the effect of site preparation on soil $\mathrm{C}$ contents.

\subsection{Soil sampling}

In March 1999, prior to harvesting, 40 soil samples were randomly collected from the $0-15,15-45$ and $45-105 \mathrm{~cm}$ depth increments on a $100 \mathrm{~m} \times 100 \mathrm{~m}$ grid for pre-harvest 
soil C measurements. In 2000 (year 1) and 2003 (year 3), soil samples were collected from three random locations in each plot at four sample depths $(0-15,15-30,30-45$ and $45-105 \mathrm{~cm}$ ) using a bucket auger. The two upper depths were composite samples from three random locations within the plot because of high spatial variation at the surface, and the two lower depths were collected at just one of the location. Care was taken to exclude any soil not from the sampling depth. For lower depths, the auger was placed carefully back into the sampling hole to reduce entry of top soil into the hole. On all occasions, except for the $0-15 \mathrm{~cm}$ depth, loose soil on top of an auger sample was removed by rotating the extracted auger at a slight tilt from horizontal so that loose material would fall out. The color differences of gray top soil on top of a yellow subsoil sample aided the removal of contamination. Prior to analysis, samples were air dried and sieved through a $2 \mathrm{~mm}$ screen to remove roots and break up clods. Total soil $\mathrm{C}$ concentrations were determined by combustion analysis using a Perkin-Elmer Series II CHNS/O Analyzer Model 2400 (Perkin-Elmer, Wellesley, MA). In years 1 and 3, three samples from random locations within each plot were collected with a lined AMS soil sampler (American Falls, ID) for bulk density measurements. Five centimeter wide by $5 \mathrm{~cm}$ long samples were collected from the upper portion of each depth increment and weighed after drying at $105^{\circ} \mathrm{C}$. The samples were then corrected for root weight and volume. No bulk density determinations were made for the pre-harvest samples.

\subsection{Soil fractionation}

Fractionation of the soil samples was done using established procedures [30,31]. Twenty grams of soil were shaken for $15 \mathrm{~h}$ with $100 \mathrm{ml}$ of a $0.5 \%(\mathrm{w} / \mathrm{w})$ solution of sodium hexametaphosphate. The dispersed soil sample was passed through a $0.053-\mathrm{mm}$ mesh (no. 270) sieve. The material remaining on the sieve was washed with deionized water, dried at $60^{\circ} \mathrm{C}$ and then weighed. This fraction is particulate organic matter and contains free organic debris and some larger fragments of organic matter released by dispersion of soil aggregates (i.e., labile organic matter). The material passing through the sieve was evaporated to dryness in a $60{ }^{\circ} \mathrm{C}$ and weighed. This fraction contains the mineral associated or stabilized $\mathrm{C}$ fraction [32]. Total $\mathrm{C}$ concentration was determined for whole samples and each fraction by combustion analysis with a Carlo Erba NA 1500 Series II $\mathrm{C} / \mathrm{N} / \mathrm{S}$ analyzer (Fisons Instruments, Danvers, MA).

\subsection{Statistical analysis}

Treatment effects on soil $\mathrm{C}$ contents and stabilized soil C contents were determined using the PROC MIXED procedure in SAS statistical software version 9.12 (SAS corporation, Cary, NC). Treatment effects by depth were conducted across all genotypes and for each genotype independently. Additionally, the effects of soil tillage on third year total soil $\mathrm{C}$ and stabilized soil $\mathrm{C}$ contents were examined. Differences in treatment means were determined using Tukey's studentized range test.

\section{Results}

\subsection{Carbon change}

Three years after study installation, soil C concentrations were not statistically different between treatments $(p=0.55)$ but were significantly lower than year 1 values $(p=0.004)$ (Fig. 1A). The year 1 values were higher than pre-harvest values; however, by the third year, soil $\mathrm{C}$ concentrations were comparable to pre-harvest values. Bulk densities were not statistically different $(p=0.19)$ in years 1 and 3 at any depth (Fig. 1B). No bulk density measurements were taken in the pre-harvest sampling; however, since there was no statistical difference in bulk density for years 1 and 3, it was assumed that they approximated pre-harvest bulk densities. Consequently, year 3 bulk density measures were used in the calculation of $\mathrm{C}$ content for the pre-harvest sampling. In the third year, $\mathrm{C}$ contents were significantly lower than year 1 levels $(p=0.01)$ and, presumably, pre-harvest levels (Fig. 1C).

\subsection{Site preparation}

To determine the effects of site preparation (soil tillage and biomass incorporation), year 3 soil $\mathrm{C}$ contents were compared between the CON treatment (harvested and site preparation) plots and the unprepared (harvested with no site preparation) plots. Soil $\mathrm{C}$ contents were generally higher at all depths for the CON treatment than the unprepared plots (Fig. 2). An exception was noted at the $45-105 \mathrm{~cm}$ depth in which tillage/biomass incorporation resulted in lower soil C contents. Soil tillage/ biomass incorporation and depth effects were significant ( $p=0.09$ and 0.0002 , respectively) as was their interaction $(p=0.03)$. In the upper $45 \mathrm{~cm}$, the CON plots had approximately $1.7-3.6 \mathrm{Mg} \mathrm{ha}^{-1}$ more $\mathrm{C}$ than the unprepared plots, for a given depth increment. At the 45-105 depth, the CON plots had $1.6 \mathrm{Mg} \mathrm{ha}^{-1}$ less soil $\mathrm{C}$ content. For all depths, some of the additional soil $\mathrm{C}$ was stabilized by its association with the mineral component (Fig. 3).

\subsection{Treatments}

Examination of the treatments (i.e., irrigation and fertilization) and genotype effects across all depths indicated no significant $(p>0.1)$ effects or interactions with the exception of the genotype $\mathrm{X}$ fertilization interaction $(p=0.06)$. When the treatment effects on each individual genotype were examined, no significant 


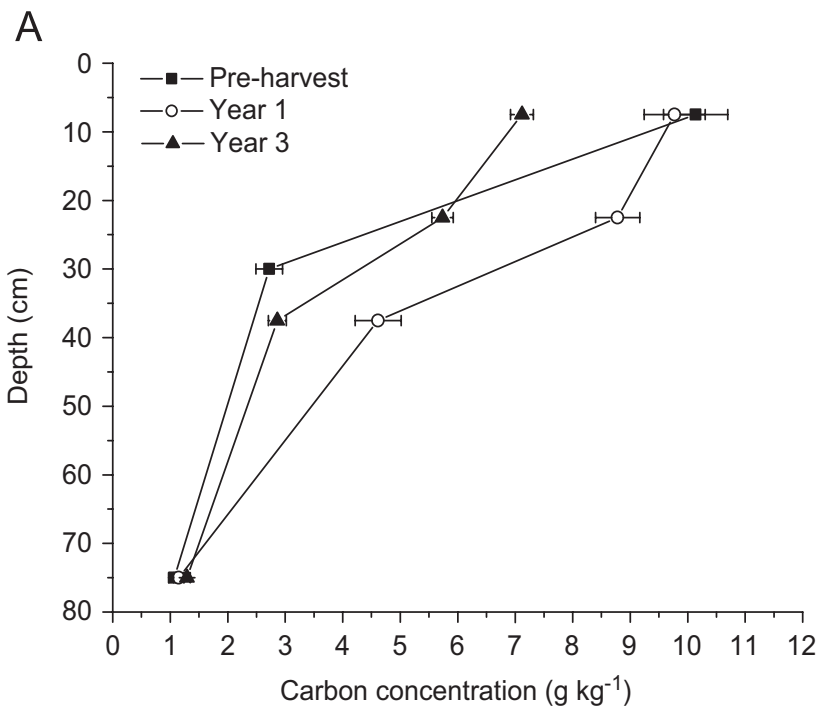

B

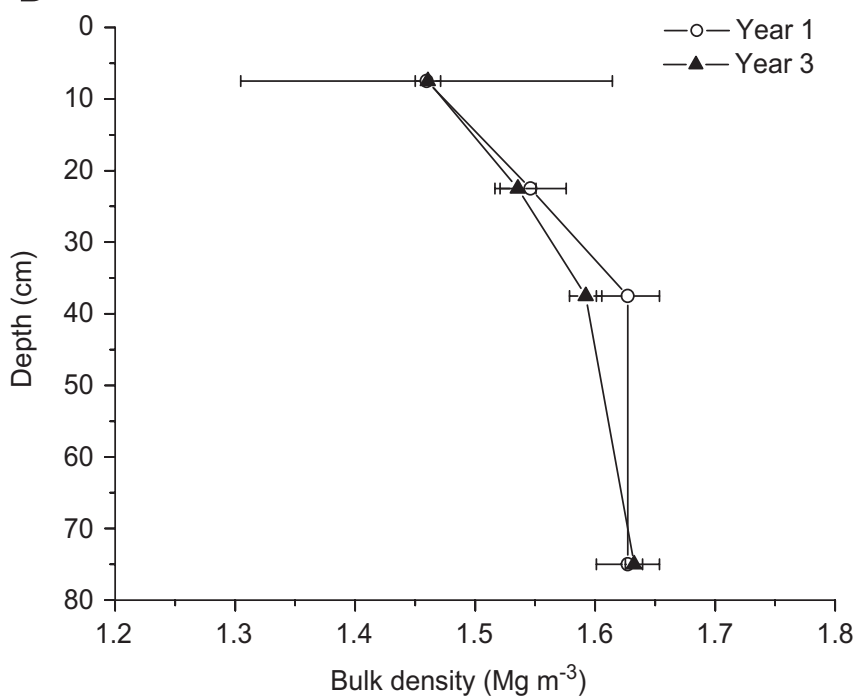

C

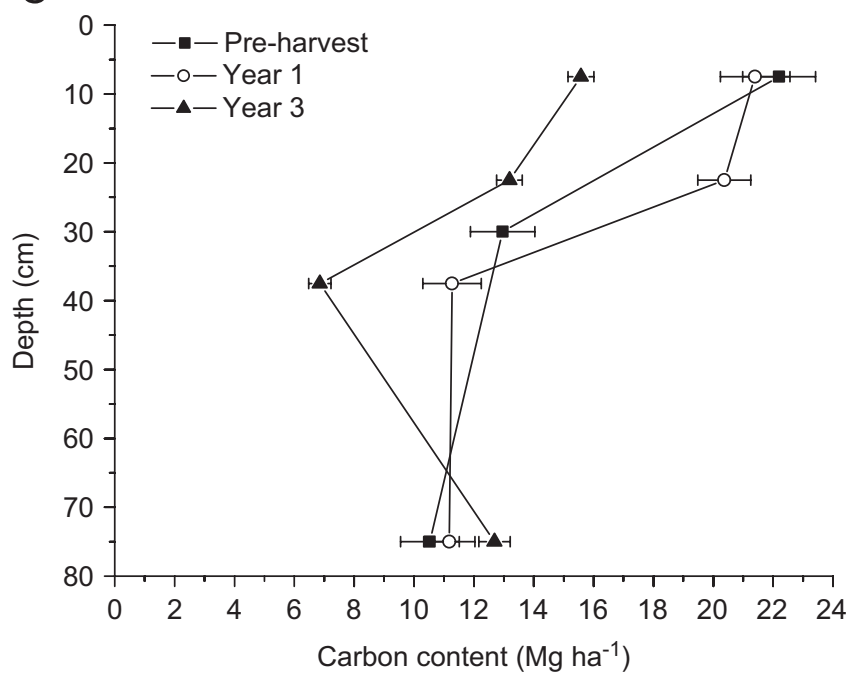

Fig. 1. (A) Mean carbon concentrations at each depth for pre-harvest, and years 1 and 3 samplings. Depths shown are the mid-point of the depth increment sampled. (B) Mean bulk density measures at each depth for preharvest, and years 1 and 3 samplings. Depths shown are the mid-point of the depth increment sampled. (C) Mean carbon contents for each depth for pre-harvest, and years 1 and 3 samplings. Depths shown are the midpoint of the depth increment sampled.

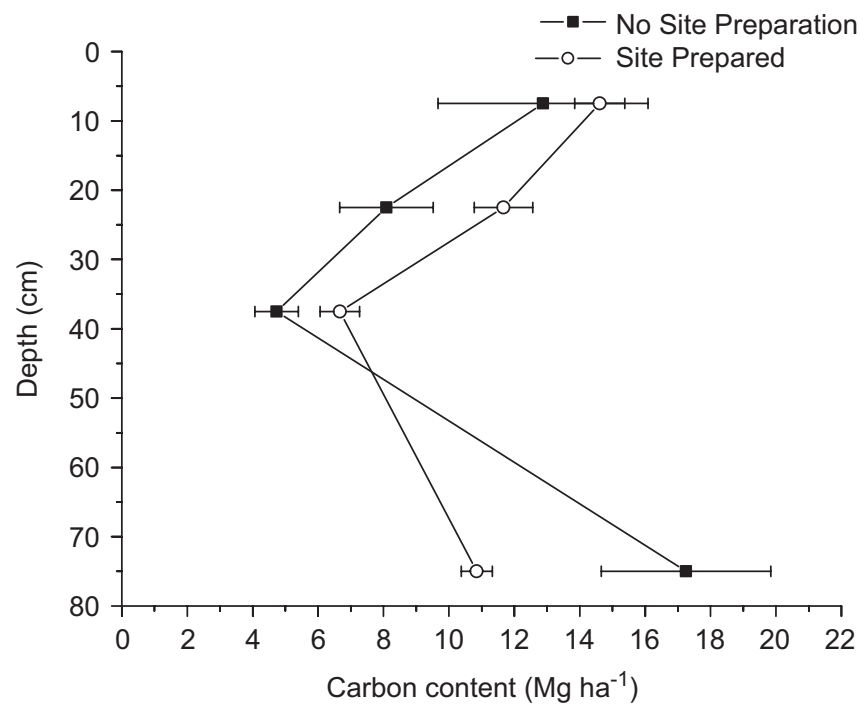

Fig. 2. Effect of site preparation on third year soil carbon contents. Depths shown are the mid-point of the depth increment sampled.

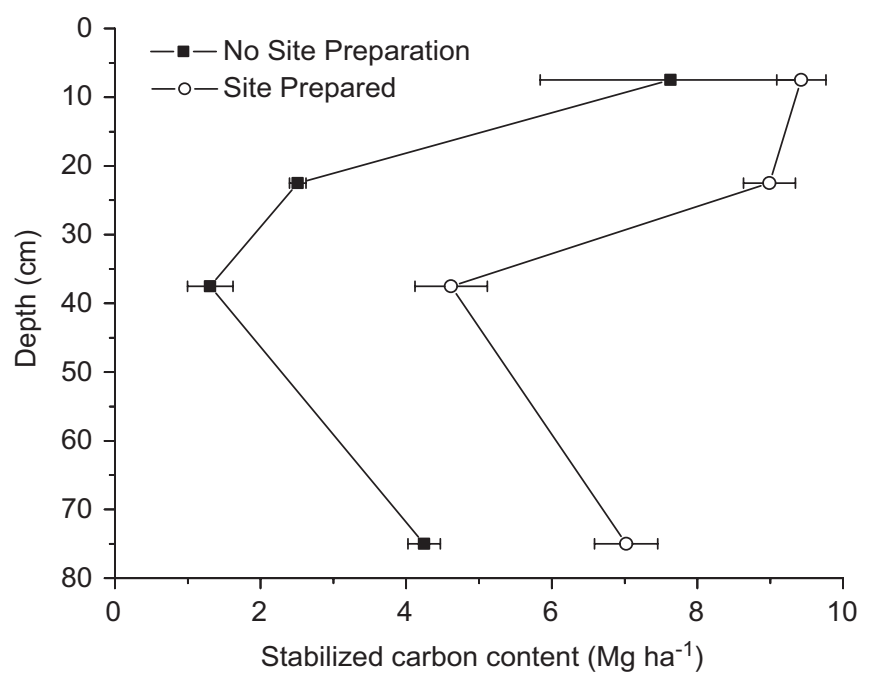

Fig. 3. Effect of site preparation on third year stabilized soil carbon contents. Depths shown are the mid-point of the depth increments sampled.

$(p>0.1)$ differences were detected between treatments or their interactions (data not shown). An exception was the cottonwood ST66 clone. For this clone, fertilization and depth effects were significant $(p=0.02$ and $p<0.0001$, respectively) while irrigation did not result in a significant effect $(p=0.22)$ and there were no significant interactions. In the upper $30 \mathrm{~cm}$ of the mineral soil, the cottonwood ST66 clone on the IF plots had higher soil C content than the cottonwood ST66 clone on the other treatment plots (Fig. 4). Portions of the increased soil $\mathrm{C}$ content was stabilized by its association with soil minerals (Fig. 5). In an analogous manner to the total soil $\mathrm{C}$ content, stabilized $\mathrm{C}$ contents had significant fertilization and depth effects ( $p=0.08$ and $p<0.0001$, respectively), but irrigation was not a significant effect $(p=0.16)$. 


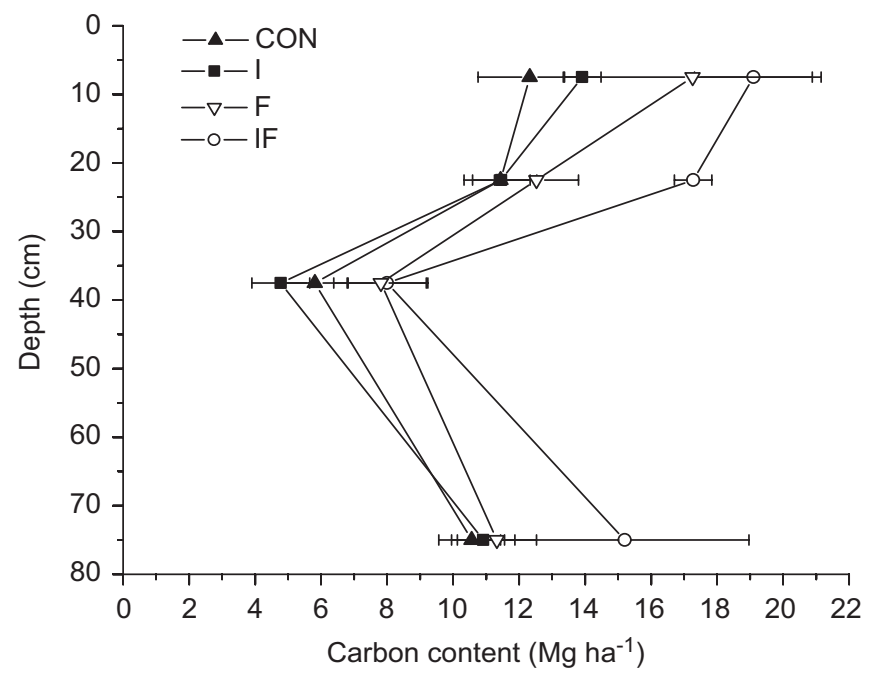

Fig. 4. Treatment effects on third year soil carbon contents for cottonwood ST66. Depths shown are the mid-point of the depth increment sampled.

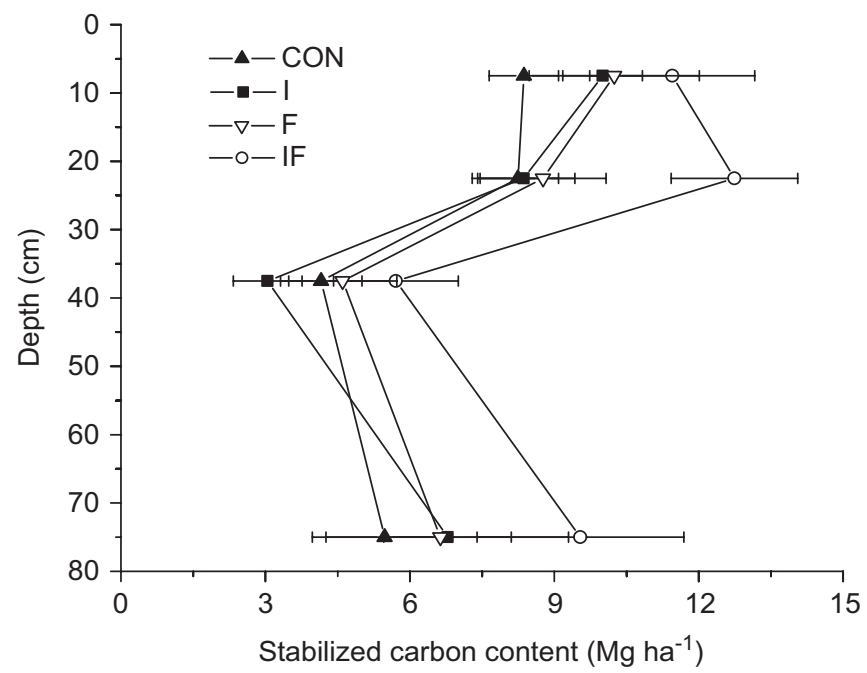

Fig. 5. Treatment effects on third year stabilized soil carbon contents for cottonwood ST66. Depths shown are the mid-point of the depth increment sampled.

\section{Discussion}

\subsection{Carbon change}

Generally there is a loss of soil $\mathrm{C}$ immediately after a harvest due to the rapid loss of labile C [33]. However, soil $\mathrm{C}$ concentrations rebounded by the first year to levels higher than before harvest probably due to inputs from decomposing necromass $[27,34]$. In the southeastern United States, the temperate climate and active decomposer organisms results in rapid decomposition of organic matter [35]. This increase in soil $\mathrm{C}$ was short lived with third year soil $\mathrm{C}$ concentrations approaching pre-harvest levels. The lack of a significant treatment effect on soil $\mathrm{C}$ concentrations $(p=0.55)$ in the third year sampling suggest that site resources (i.e., water and nutrients) are sufficient to drive the $\mathrm{C}$ dynamics at this site and additional water or nutrients do not significantly alter the $\mathrm{C}$ dynamics. An exception to this observation will be discussed in Section 4.3.

Although it is a reasonable expectation to see soil compaction after a harvest, no direct determination of compaction can be made since there were no pre-harvest bulk density measurements; however, there was no significant difference $(p=0.19)$ in bulk densities between years 1 and 3 . This suggests that any soil compaction from the harvest operation had recovered by the first year. Soil tillage was probably the main contributor to this recovery. Sandy soils, such as those on this study, with initial bulk densities greater than $1.2 \mathrm{Mg} \mathrm{m}^{-3}$ generally do not compact to a large degree and recover rapidly, even when extensive efforts are exerted to compact the soil $[23,36]$. Consequently, it is reasonable to use the third year bulk density measures as a proxy for pre-harvest values in the calculation of soil $\mathrm{C}$ contents.

A change in $\mathrm{C}$ contents can only occur when $\mathrm{C}$ loss and $\mathrm{C}$ gain are not equal. The probable labile $\mathrm{C}$ lost during the harvest seems to have been replenished by the first year suggesting that decomposition of necromass is contributing more $\mathrm{C}$ than is being lost through respiration or leaching. The additional $\mathrm{C}$ is coming primarily from decomposing necromass as $\mathrm{C}$ contributions from the forest floor and first year root systems would be small. Powers et al. [23] observed similar increases in some of their study sites, and attributed the increases to variations in sampling, increases in bulk density and input from decomposing necromass. By the third year, $\mathrm{C}$ contents have dropped to below preharvest values. At this stage, it is probable that the necromass decomposed in the first year has undergone further oxidation resulting in $\mathrm{C}$ loss through respiration or leaching and this $\mathrm{C}$ loss is greater than the $\mathrm{C}$ contribution by roots or the forest floor.

The physical capacity of a soil to protect organic matter is dependent on soil texture and the amount of organic matter already protected (i.e., stabilized) [18,32,37,38]. Hassink and Whitmore [38] developed a model relating the physical protection of organic matter to soil texture. Their model suggested that soils, regardless of texture, could maintain a minimum of $21.1 \mathrm{~g} \mathrm{C} \mathrm{kg}^{-1}$ soil. They were not suggesting that all soils had a minimum of $21.1 \mathrm{~g} \mathrm{C} \mathrm{kg}^{-1}$ soil but that they could maintain that amount through physical stabilization. The soils in our study were generally below $10 \mathrm{~g} \mathrm{C} \mathrm{kg}^{-1}$ soil at all depths so, according to the model developed by Hassink and Whitmore [38], there is potential to increase the soil C contents of these soils. This was not observed in our study, where there was a loss of $\mathrm{C}$ by the third year as compared with pre-harvest. However, the proportion of $\mathrm{C}$ stabilized in the soil for the different samplings remained remarkably consistent (Table 2). The $\mathrm{C}$ stabilization model of Hassink and Whitmore [38] described a steady-state condition, where the amount of labile $\mathrm{C}$ entering the stabilized $\mathrm{C}$ pool was 
equal to the amount of stabilized $\mathrm{C}$ entering the labile $\mathrm{C}$ pool. This condition seems to describe our observations where the proportion of stabilized $\mathrm{C}$ remained approximately in the mid- to upper 60 percentile.

\subsection{Site preparation}

Generally, site preparation resulted in an increase in third year soil $\mathrm{C}$ contents at all depths except for the $45-105 \mathrm{~cm}$ depth increment where there was a loss of soil C content (Fig. 2). Theoretically, the RS-500 Reclaimer/ Stabilizer should distribute the necromass evenly within the 0-30 $\mathrm{cm}$ depth increment. In practice, a large component of the organic matter was concentrated at the $15-30 \mathrm{~cm}$ depth. This may explain why the largest increase in soil $\mathrm{C}$ content due to tillage was at the $15-30 \mathrm{~cm}$ depth increment. The increases observed at the $30-45 \mathrm{~cm}$ depth may be due to soil settling, transport of masticated material from the upper depths by soil fauna, and infusion of dissolved organic matter (DOM) from the upper depths, particularly if the disturbance from the tillage accelerated decomposition of soil organic matter.

Decomposition of masticated material in the upper depths (i.e., $0-30 \mathrm{~cm}$ ) and probable vertical movement of DOM on these sandy sites resulted in an influx of organic matter at all depths. The $\mathrm{C}$ added during the tillage was partially stabilized by its association with soil minerals (Fig. 3). The amount of stabilized $\mathrm{C}$ relative to labile $\mathrm{C}$ (Fig. 6) and total $\mathrm{C}$ (Table 1) indicates a substantial stabilization of the incorporated material. Garten and Ashwood [39] demonstrated that C stabilized by its association with soil minerals have turnover times ranging from 18 to 141 years, depending on ecosystem conditions, with an average turnover time of 56 years; thus, providing an effective means of $\mathrm{C}$ storage (Table 2).

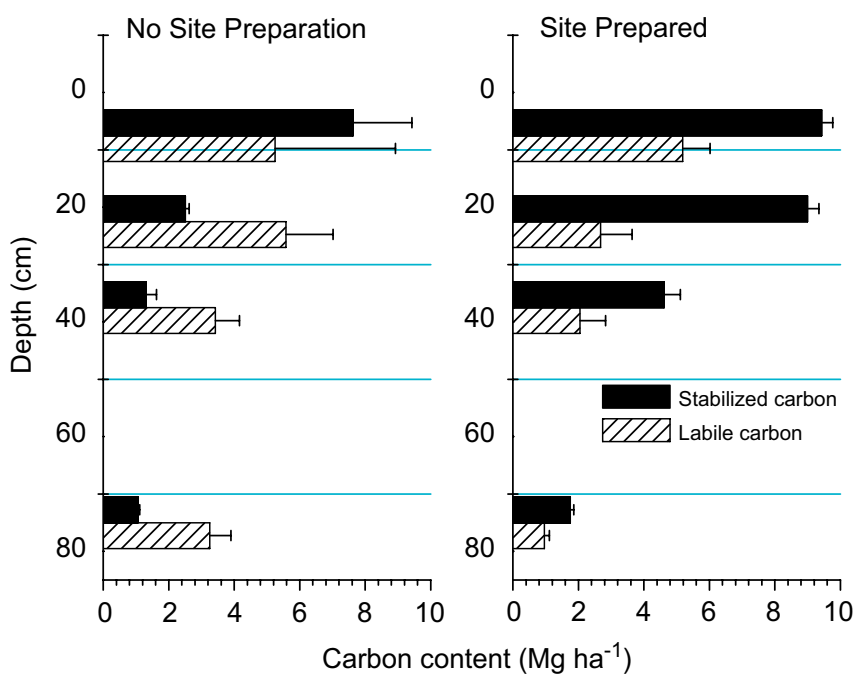

Fig. 6. Mean labile and stabilized carbon contents for each depth in the plots with and without site preparation. Depths shown are the mid-point of the depth increment sampled.
Table 1

Percentage of total soil carbon being stabilized by its association with soil minerals

\begin{tabular}{|c|c|c|}
\hline \multirow[t]{3}{*}{ Depth increment $(\mathrm{cm})$} & \multicolumn{2}{|l|}{ Treatment } \\
\hline & Harvest/no till & $\mathrm{CON}$ \\
\hline & \multicolumn{2}{|c|}{ Percent stabilized carbon ${ }^{\mathrm{a}}(\%)$} \\
\hline $0-15$ & 59.28 & 64.51 \\
\hline $15-30$ & 31.03 & 77.05 \\
\hline $30-45$ & 27.65 & 69.24 \\
\hline $45-105$ & 24.62 & 64.71 \\
\hline
\end{tabular}

${ }^{\text {a }}$ Percent stabilized carbon $=100^{*}$ (stabilized carbon content $/$ total carbon content).

Table 2

Percentage of the total soil $\mathrm{C}$ that is stabilized by its association with soil minerals

\begin{tabular}{llll}
\hline Sampling & Percent stabilized C (\%) & Standard error & $P$ value $^{\mathrm{a}}$ \\
\hline Pre-harvest & 64.34 & 0.98 & \\
Year 1 & 68.31 & 0.73 & 0.63 \\
Year 3 & 67.47 & 1.32 & \\
\hline
\end{tabular}

${ }^{\text {a }} P$ values are shown only for comparison between the years 1 and 3 samplings.

\subsection{Treatments}

Across all treatment and genotypes, there were no significant main effects in the third year, but there was a significant genotype $\mathrm{X}$ fertilization interaction $(p=0.06)$, which resulted primarily from the significant fertilization effect $(p=0.02)$ in the plots planted with the cottonwood ST66 clone. Although there was no significant irrigation $\mathrm{X}$ fertilization interaction $(p=0.30)$ for these plots, the combination of irrigation plus fertilization resulted in an additive effect that increased soil $\mathrm{C}$ contents as compared with the CON treatment (Fig. 4). Since soil tillage should result in a more homogenous soil condition, any differences in soil $\mathrm{C}$ contents should primarily come from live root inputs. Mean annual belowground biomass for cottonwood ST66 on the IF treatment plots was more than double that of the CON plots in the third year (0.6 and $2.0 \mathrm{Mg} \mathrm{ha}^{-1}$ year $^{-1}$, respectively) (Table 3) [9]. Coyle and Coleman [9] also found that fertilization significantly $(p \leqslant 0.01)$ increased fine root biomass for cottonwood ST66 trees but had no significant affect on cottonwood S7C15 and sycamore trees. Additionally, the concentration of necromass at the $15-30 \mathrm{~cm}$ depth due to tillage may result in a more favorable soil environment (i.e., higher nutrients and soil moisture) for root development and yield the observed larger effects at this depth increment.

Guo et al. [17] determined that fine root density and not total fine root biomass produced was the critical factor in controlling how soil C stocks would be affected by roots. The response of the cottonwood ST66 clone to the IF treatment suggests that root development in the 
Table 3

Mean annual biomass production $\left(\mathrm{Mgha}^{-1}\right.$ year $\left.^{-1}\right)$ of sycamore, cottonwood ST66 and cottonwood S7C15 after 3 years from Coyle and Coleman [9]

\begin{tabular}{llll}
\hline Treatment & Aboveground & Belowground & Total \\
\hline ST66 & & & \\
CON & $0.6 \pm 0.1$ & $0.6 \pm 0.1$ & $1.2 \pm 0.2$ \\
I & $1.1 \pm 0.4$ & $1.0 \pm 0.2$ & $2.1 \pm 0.5$ \\
F & $1.8 \pm 0.4$ & $1.6 \pm 0.2$ & $3.4 \pm 0.6$ \\
IF & $3.1 \pm 0.5$ & $2.0 \pm 0.2$ & $5.1 \pm 0.7$ \\
S7C15 & & & \\
CON & $0.8 \pm 0.1$ & $0.8 \pm 0.1$ & $1.5 \pm 0.2$ \\
I & $1.7 \pm 0.5$ & $1.1 \pm 0.1$ & $2.8 \pm 0.6$ \\
F & $1.8 \pm 0.2$ & $1.2 \pm 0.2$ & $3.0 \pm 0.2$ \\
IF & $3.2 \pm 0.5$ & $1.8 \pm 0.2$ & $5.0 \pm 0.6$ \\
Sycamore & & & \\
CON & $1.5 \pm 0.1$ & $1.1 \pm 0.1$ & $2.6 \pm 0.2$ \\
I & $3.5 \pm 0.4$ & $2.1 \pm 0.1$ & $5.7 \pm 0.4$ \\
F & $3.3 \pm 0.2$ & $2.3 \pm 0.1$ & $5.7 \pm 0.1$ \\
IF & $6.3 \pm 0.9$ & $3.1 \pm 0.2$ & $9.4 \pm 0.7$ \\
\hline
\end{tabular}

cottonwood ST66 clone may have been stimulated by the treatment. Both cottonwood clones had significant positive growth responses to fertilization but only the ST66 clone had a positive response to irrigation [28], but this effect largely disappeared by the third year [9]. The combination of irrigation and fertilization had an additive effect on tree growth [28] and belowground biomass [9] for these clones.

As was observed in the examination of the tillage effect on soil $\mathrm{C}$ contents, a large portion of the increased soil $\mathrm{C}$ contents in the IF treatment as compared with the other treatments for cottonwood ST66 was partially stabilized by its associated with minerals (Fig. 5). The observed C increases in the treatment comparisons is from root inputs since all of the treatment plots were tilled with incorporation of masticated material. The origin of the additional C (i.e., masticated material versus root inputs) may determine how persistent the $\mathrm{C}$ increases will be. Logging slash and large root systems from the previous stand will probably be more resistant to decomposition than live root inputs primarily fine roots. Logging slash and old root systems would be larger, coarser and have higher $\mathrm{C}: \mathrm{N}$ ratios than live root inputs which would contribute to slower rates of decomposition. In a study investigating the build up and persistence of soil C near live roots, Sanchez and Bursey [40] demonstrated the transient nature of soil C originating from live roots. This research coupled with the observation that the unprepared plots (harvested but not tilled) had high levels of labile C (Fig. 6) suggests that the observed soil $\mathrm{C}$ increases may persist for only a few years.

What may be more relevant to long term $\mathrm{C}$ sequestration goals is the increase in belowground biomass. The larger belowground biomass realized in these managed systems may persist long after the stand is harvested. Ludovici et al. [22] demonstrated that loblolly pine stumps remaining after a harvest can persist for several decades in a silty loam soil.
Root decay could lead to high levels of localized concentrated $\mathrm{C}$ [21] and has been found to have an overriding influence on soil C contents [23]. Root decomposition rates will vary by factors such as genotype, soil texture and drainage but will probably be in the same magnitude as observed by Ludovici et al. [22]. Even so, buried root systems (i.e., coarse and tap roots) are a larger source of $\mathrm{C}$ and may persist much longer than $\mathrm{C}$ inputs from masticated forest slash or fine roots.

\section{Conclusions}

The utilization of short-rotation woody crops with ample resource (i.e., water and nutrients) availability is a strategy for the rapid production of fiber and wood products necessary on the global scale. Additionally, site preparation methods such as tilling and incorporation of soil amendments (i.e., forest slash) further improve the potential for greater biomass production. These intensively managed stands could also increase soil $\mathrm{C}$ stocks from the increase in the belowground biomass contribution to soil $\mathrm{C}$ pools. However, the potential increases in soil $\mathrm{C}$ contents were not realized in this study primarily because there was a decrease in soil $\mathrm{C}$ concentrations following harvest. Despite an influx of soil $\mathrm{C}$ in the first year, third year soil C contents were lower than pre-harvest estimates probably because of further decomposition of soil organic matter.

In the third year, fertilization increased soil $\mathrm{C}$ contents for the cottonwood ST66 clone whereas irrigation did not have a significant effect. There were no significant treatment effects for any other genotype examined. Although irrigation was not a significant effect for the cottonwood ST66 clone, it had an additive effect to the fertilization treatment. This effect was most evident in the upper $30 \mathrm{~cm}$ of mineral soil where the majority of cottonwood root system resides. This effect was not observed in the other cottonwood clone (S7C15) used in this study. A possible explanation for this observation comes from the origins of the two clones. Cottonwood ST66 originates along the Mississippi delta and more responsive to water and nutrient additions; whereas, the cottonwood S7C15 clone originates from Texas and may be more tolerant of water and nutrient limitations.

In all cases where there was an observed increase in soil $\mathrm{C}$ contents, there was a concurrent increase in the amount of stabilized $\mathrm{C}$ contents. However, the net amount of $\mathrm{C}$ stabilized, regardless of sampling date, remained relatively consistent at around mid- to upper 60 percentages. These observations suggest that by the third year, these soils may have reached a steady state but not necessarily their maximum protective capacity, as proposed by Hassink and Whitmore [38]. In addition to physical protection, another factor that must be considered is the inherent chemical stability of the organic matter. As the organic matter's composition increases in microbially resistant compounds, such as polyphenols and aliphatics, its stability in the soil should increase. Root inputs 
generally have lower concentrations of recalcitrant materials, whereas masticated forest slash would have a larger relative proportion of chemically recalcitrant compounds. However, what may be more important to soil C sequestration goals may be in the persistence of the belowground root system after harvest. If intensive management of short-rotation woody crops is successful in increasing above- and belowground biomass, the amount of material (i.e., root systems) that we leave buried after a harvest may be the preferred mechanism for longterm soil $\mathrm{C}$ sequestration.

\section{Acknowledgments}

Support was provided by the Department of EnergySavannah River Operations Office through the US Forest Service Savannah River under Interagency Agreement DEAI09-00SR22188 and by the Department of Energy's Office of Science, Biological and Environmental Research funding to the Consortium for Research on Enhancing Carbon Sequestration in Terrestrial Ecosystems (CSiTE).

\section{References}

[1] Dickmann DI, Stuart KW. The culture of poplars in Eastern North America. East Lansing, MI: Michigan State University Press; 1983.

[2] Allen HL, Dougherty PM, Campbell RG. Manipulation of water and nutrients - practice and opportunity in Southern US pine forests. Forest Ecology and Management 1990;30:437-53.

[3] Cao QV, Durand KM. A growth and yield model for improved eastern cottonwood plantations in the lower Mississippi Delta. Southern Journal of Applied Forestry 1991;15(4):213-6.

[4] Stanturf JA, van Oosten C, Netzer DA, Coleman MD, Portwood CJ. Ecology and silviculture of poplar plantations. In: Dickmann DI, Isebrands JG, Eckenwalder JE, Richardson J, editors. Poplar culture in North America. Ottawa, Canada: National Research Council; 2001. p. 153-206.

[5] Yin R, Sedjo RA. Is this the age of intensive management? A study of loblolly pine in Georgia's Piedmont. Journal of Forestry 2001;99: $10-7$.

[6] Lockaby G, Clawson R, Baker T. Response of three hardwood species to irrigation and fertilization on an upland site. Southern Journal of Applied Forestry 1997;21(3):123-9.

[7] Tuskan GA. Short-rotation woody crop supply systems in the United States: what do we know and what do we need to know? Biomass and Bioenergy 1998;14:307-15.

[8] Samuelson L, Stokes T, Cooksey T, McLemore P. Production efficiency of loblolly pine and sweetgum in response to four years of intensive management. Tree Physiology 2001;21:369-76.

[9] Coyle DR, Coleman MD. Forest production responses to irrigation and fertilization are not explained by shifts in allocation. Forest Ecology and Management 2005;208:137-52.

[10] Johnson DW. Carbon in forest soils - research needs. New Zealand Journal of Forestry Science 1993;23:354-66.

[11] Hansen EA. Soil carbon sequestration beneath hybrid poplar plantations in the north central United States. Biomass and Bioenergy 1993;5:431-6.

[12] Smith CT. Environmental consequences of intensive harvesting. Biomass and Bioenergy 1995;9:161-79.

[13] Grigal DF, Berguson WE. Soil carbon changes associated with shortrotation systems. Biomass and Bioenergy 1998;14:371-8.

[14] Cannell MGR. Forests as carbon sinks mitigating the greenhouse effect. Commonwealth Forestry Review 1996;75:92-9.
[15] Farrar JE, Jones DL. The control of carbon acquisition by and growth of roots. In: de Kroom H, Visser EJW, editors. Root ecology. New York: Springer; 2003. p. 91-124.

[16] Mehdi B, Zan C, Girouard P, Samson R. Soil organic carbon sequestration under two dedicated perennial bioenergy crops. In: Overend RP, Chornet E, editors. Biomass: a growth opportunity in green energy and value-added products, Proceedings of the fourth biomass conference on the Americas, 1999. p. 17-23.

[17] Guo LB, Halliday MJ, Siakimotu SJM, Gifford RM. Fine root production and litter input: its effects on soil carbon. Plant and Soil 2004;272(1\&2):1-10.

[18] West JB, Espeleta JF, Donovan LA. Fine root production across a complex edaptic gradient of a Pinus palustris-Aristida stricta savanna ecosystem. Forest Ecology and Management 2004;189: 397-406.

[19] Devine WD, Mullen MD, Tyler DD, Houston AE, Joslin JD, Hodges DG, et al. Conversion from a sycamore biomass crop to a no-till corn system: effects on soils. Soil Science Society of America Journal 2004;68:225-33.

[20] Garten Jr CT. Soil carbon storage beneath recently established tree plantations in Tennessee and South Carolina, USA. Biomass and Bioenergy 2002;23:93-102.

[21] Van Leer DH, Kapeluck PR, Carroll WD. Productivity of loblolly pine as affected by decomposing root systems. Forest Ecology and Management 2000;138:435-43.

[22] Ludovici KH, Zarnoch SJ, Richter DD. Modeling in-situ pine root decomposition using data from a 60-year chronosequence. Canadian Journal of Forest Research 2002;32:1675-84.

[23] Powers RF, Scott DA, Sanchez FG, Voldseth RA, Page-Dumroese $\mathrm{D}$, Elioff JD, et al. The North American long-term soil productivity experiment. Findings from the first decade of research. Forest Ecology and Management 2005;220(1-3):17-30.

[24] Buford MA, Stokes BJ, Sanchez FG, Carter EA. Using biomass to improve site quality and carbon sequestration. In: Lowe AT, Smith CT, editors. Developing systems for integrating bioenergy into environmentally sustainable forestry, Proceedings of the IEA bioenergy task 18 workshop and joint workshop with task 25 , NZ FRI, For. Res. Bull. No. 211, 1999. p. 97-103.

[25] Buford MA, Stokes BJ. Incorporation of biomass into forest soils for enhanced productivity, restoration, and biostorage: a modeling study to evaluate research needs. New Zealand Journal of Forestry Science 2000;30(1\&2):130-7.

[26] Sanchez FG, Carter EA, Klepac J. Soil carbon and soil physical properties response to forest slash incorporation. New Zealand Journal of Forestry Science 2000;30(1-2):150-68.

[27] Sanchez FG, Carter EA, Klepac JF. Enhancing the soil organic matter pool through biomass incorporation. Biomass and Bioenergy 2003;24:337-49.

[28] Coleman MD, Coyle DR, Blake J, Britton K, Buford M, Campbell B, et al. Production of short rotation woody crops Grown with a range of nutrient and water availability: establishment report and first-year responses. USDA-Forest Service, Southern Research Station, Gen. Tech. Rep. SRS-72, 2004.

[29] Rogers VA. Soil survey of Savannah River Plant area. Parts of Aiken, Barnwell, and Allendale counties, South Carolina. Washington, DC: USDA Soil Conservation Service; 1990.

[30] Kettler TA, Doran JW, Gilbert TL. Simplified method for soil particle-size determination to accompany soil-quality analyses. Soil Science Society of America Journal 2001;65:849-52.

[31] Cambardella CA, Elliott ET. Particulate soil organic matter changes across a grassland cultivation sequence. Soil Science Society of America Journal 1992;56:777-83.

[32] Kahle M, Kleber M, Torn MS, Jahn R. Carbon storage in coarse and fine clay fractions of Illitic soils. Soil Science Society of America Journal 2003;67:1732-9.

[33] Johnson DW, Curtis PS. Effects of forest management on soil C and $\mathrm{N}$ storage: meta analysis. Forest Ecology and Management 2001;140:227-38. 
[34] Sanchez FG, Tiarks AE, Kranabetter JM, Page-Dumroese DS, Powers RF, Sanborn PT, et al. Effects of organic matter removal and soil compaction on fifth-year mineral soil carbon and nitrogen contents for sites across the United States and Canada. Canadian Journal of Forest Research 2006;36:565-76.

[35] Tiarks A, Klepzig K, Sanchez F, Lih M, Powell J, Buford M. Roles of coarse woody debris in the loblolly pine ecosystem. In: Haywood JD, editor. In: Proceedings of the tenth biennial southern silviculture research conference, Gen. Tech. Rep. SRS-30, Asheville, NC, US Department of Agriculture, Forest Service, Southern Research Station, 1999. p. 238-42.

[36] Page-Dumroese DS, Jurgensen MF, Tiarks AE, Ponder Jr F, Sanchez FG, Fleming RL, et al. Soil physical property changes at the North American long-term soil productivity study sites: 1 and 5 years after compaction. Canadian Journal of Forest Research 2006;36: 551-64.

[37] Amato M, Ladd JN. Decomposition of ${ }^{14} \mathrm{C}$-labelled glucose and legume material in soils: properties influencing the accumulation or organic residue $\mathrm{C}$ and microbial biomass $\mathrm{C}$. Soil Biology \& Biochemistry 1992;24:455-64.

[38] Hassink J, Whitmore AP. A model of the physical protection of organic matter in soils. Soil Science Society of America Journal 1997;61:131-9.

[39] Garten Jr CT, Ashwood TL. Landscape level differences in soil carbon and nitrogen: implication for soil carbon sequestration. Global Biogeochemical Cycles 2002;16:art. no. 1114.

[40] Sanchez FG, Bursey MM. Transient nature of rhizosphere carbon elucidated by supercritical freon-22 extraction and ${ }^{13} \mathrm{C}$ NMR analysis. Forest Ecology and Management 2002;169:177-85. 